\title{
炭鉱廃石の利 用
}

座長向山広*

10月17日（火）13時より開会され，つぎの 4 つの講演 とそれに対する熱心な質疑が行なわれた。

筑豊炭田の夾炭層に伴う粘士鉱物…………向山 広

高島炭砸における炭層中の耐火粘

土について…………………………家坂貞男

日本炭砸におけるボ夕利用………………坂本隆泰

幌内膨張頁岩の人工軽量骨材への利用……対馬英二

これらの内容については本稿に続いて掲載されている

講演要旨に記載されているので，それ趁照して頂き たい。

つぎに各講演に対する主な質疑をまとめて掲載した。 ご繁忙のところご講演頂いた講師の方々および終始熱心 に聴講された各位に深甚なる謝意を表する。

\section{晢 疑}

[ 1. 筑豊炭田の夾炭層に伴亏粘土鉱物]

A. 質問者 : 坂本隆泰

1）筑豊における $\mathrm{Ca}$ モンモリロナイトの代表的サン プル

2）群馬, 山形のベントナイトはどのタイプのベント ナイトか

答 : 向山

1）大辻，日炭等の炭層下盤のものがもつとも濃度が 大きい。

2）は $\mathrm{Ca}$-モンモリロナイトを主とする。

B. 質問者 : 高山久雄

1）粘土鉱物の相異は基盤岩の違いによるものか，堆 積環境の違いによるものか。

2）三尺五尺層の基盤に近いところはカオリナイトが 多くなるが，漸移部はどうなるのだろうか。

答: 向山

1）は流入した土砂の性質によるものの方が大きい。

2）は調査した所が無いため，明らかでない。

C. 質問者 : 松尾敏美

筑豊炭田の遠賀川本川系々彦山川系の夾炭層鉱物な らびに火成岩の成質に差異ありや，坑内揚水は前者は $\mathrm{SO}_{2}-$ - 多く,アルカリ度が低い。また後者はアルカリ 度高く, 硫酸イオンが多い。このような特長的な対比 を示している。

答：向山

* 理博 九州大学教授 工学部採鉱学科
地質は両者間に差が無い。

[2. 高島炭砿に扔ける炭層中の耐火粘土について]

A. 質問者：諫山幸男

1）ゴマ頁岩 $\mathrm{A}$ 型， $\mathrm{B}$ 型， C 型でフライアビリティー にどのような相異があるか。

2）ゴマ頁岩の回収経費(円/t)は，

答: 家坂

実際にフライアビリティーの測定はしていないが， ゴマ頁岩をはさむゴマ五尺層(炭層)のフライアビリテ イーは35前後で，ゴマ頁岩はこれよりはるかに堅い。 $\mathrm{A} \sim \mathrm{C}$ 型のうちでは $\mathrm{A} \rightarrow \mathrm{B} \rightarrow \mathrm{C}$ 型の順で若干もろく (こわ机易く)なる。 A, B 型は炭層中の同じくらいの 厚さの頁岩夾みと変わらない程の堅さをもつている。

2)の質問は坑内採炭切羽の稼行状況により一定しな いが，昭和 39 年当時， $\mathrm{A} \sim \mathrm{B}$ 型を月 $40 \mathrm{t}$ 回収して $\mathrm{t}$ 当 たり 3,000 4,000円であつた。

[ 3. 日本炭砿に抬けるボ夕利用]

A. 質問者: 鴻栄涁

1）スライム原料の農薬キャリヤーの製造において， 焼成前に造粒してペレットを作り，また焼成後に粉 砕しているのは製品の粒度分布を変えるのが主な目 的加。

2）農薬キャリヤーの值段について

答: 坂本

特に製品の粒度分布を変えるための目的ではない。 泥漿状の原料を乾燥して焼く時, 湿式セメント方式の ロータリーキルンの場合，ぞうしても塊りとなる。そ こで乾燥炉のチエンで適当なサイズに整粒すること は，燒成炉で carbonを燒き切る時必要な条件であ る。理想から言うと，原料のミクロサイブの粒度を維 持したまま焼成することが出来ればいいと思うが実際 にはむづかしい。

2)の質問は6〜6.5円 $/ \mathrm{kg}$

B. 質問者: 滝本清

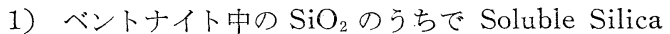
注どの位あるか。

2) Soluble Silicaの量とベントナイトの性質との関 係は。

答: 坂本 
Soluble Silica は1\%以下

2)の質問は Soluble Silica が微量であるため,ベント ナイトの性質と関連してあまり検討したことがない。

C. 質問者 : 泊正雄

ベントナイト付加物の試験条件, ペレタイシングか もしそうでなかつたら供試体の作り方

答：坂本

ペレットテストではなく，鋳物砂テストがある。鋳 物砂試験は 5〜6 号ていどの砂にベントナイト 7\%を 入れ，水を 5 6\% 添加して混練し，所定の搗固機で 28. $6 \mathrm{~mm} \phi \times 50 \mathrm{~mm}$ 円筒型の試料にしたものである。 これは九大の鋳物砂の高温テストに用いられ，砂型の 寸法で常温テストには JIS 2-2603の $5 \mathrm{cmm} \phi \times 50 \mathrm{~mm}$ が用いられている。

[4. 幌内膨張頁岩の人工軽量骨材への利用]

A. 質問者 : 坂本陸泰 ペレタイザーの種類

答 : 対馬

パン型ペレタイザー（コンクリートミキサーを改造 内径 : $1,000 \mathrm{~mm}$, 深さ : $300 \mathrm{~mm}$, 回転数 : 10 $50 \mathrm{rpm}$, モーター：1 H (減速装置付), 傾 斜 : 水平に対して 0 90 度可能

B. 質問者：野田道宏

見掛比重と吸水率と急熱急冷, 徐熱急冷の関係が示 されており，がいして徐熱急冷の場合が吸水率は小さ く出ているが，それらの要素と焼成物の表面釉（ガラ ス質）の生成との関連性はないか，認められたか。

答：対馬

急熱急冷の場合は表面に急熱の際に亀裂を生じ, 所 定温度で保持時間を長くすれば，表面のガラス化は進
むが，亀裂は完全には無くならない。また表面の褐色 皮膜 (酸化層と称している) 功薄い。徐熱急冷の場合 は表面亀裂が少なく，褐色皮膜が厚く $\left(20^{\circ} \mathrm{C} / \mathrm{min} よ\right.$ りも $10^{\circ} \mathrm{C} / \mathrm{min}$ の方が厚い), この部分の微細気孔は 斉一で独立気孔が多い。

C. 質問者 : 諫山幸男

1） ボタの造粒試験にあたつて粗粒 (20 40mesh) 80 $\%$, 微粉（一-200mesh） $20 \%$ と粒度分布を決定した理 由。

2）粒度組成による造粒焼成物の見掛比重への影響を 考慮されたか。

答：対馬

1）ショック（急熱に対する抵抗温度）. 決定に対して 上記粗粉, 微粉で数種配合して試験し, 各種条件で ショックを受けにくく，また造粒を可能であるとい うことであつて，またディスイングレーターま たはフレット粉挽ではー200mesh が 20\% 前後が多 い。

2）粗粒が多い方が見掛比重が軽くなると考えたが, 特に試験しなかつた。

D. 質問者 : 遠藤弘

軽量骨材を鉄筋コンクリートに使用した場合の経年 変化について，どのように考えているか。

答：対馬

JIS A-5002 に示される限りの骨材に忌避される化 学成分については天然骨材よりも少ないので，必要な いと思うが，天然砂利よりは吸水率が大きいので，野 積方法に注意しないと，この閒に忌避される化学成分 を吸收する可能性がある。 